\title{
SOIL CHEMICAL ATTRIBUTES VARIABILITY UNDER TILLAGE AND NO- TILLAGE IN A LONG-TERM EXPERIMENT IN SOUTHERN BRAZIL
}

\author{
VARIABILIDADE DOS ATRIBUTOS QUÍMICOS DO SOLO EM SISTEMAS DE \\ PLANTIO DISTINTOS EM EXPERIMENTO DE LONGA DURAÇÃO NO SUL DO \\ BRASIL
}

\author{
Katiaíres Evangelista Delpin MALVEZI ${ }^{1}$; Luiz Antônio ZANÃO JÚNIOR ${ }^{2}$; \\ Ednaldo Carvalho GUIMARÃES ${ }^{3}$; Sidney Rosa VIEIRA ${ }^{4}$; Natália PEREIRA $^{5}$ \\ 1. Instituto Agronômico do Paraná - IAPAR, Londrina, PR, Brasil, kmalvezi@ gmail.com; 2. Instituto Agronômico do Paraná - IAPAR, \\ Polo Regional de Santa Tereza do Oeste, Santa Tereza do Oeste, PR, Brasil; 3. Universidade Federal de Uberlândia - UFU - Faculdade \\ de Matemática, Uberlândia, MG, Brasil; 4. Instituto Agronômico - IAC, Campinas, SP, Brasil; 5. Universidade Estadual do Oeste do \\ Paraná - UNIOESTE, Cascavel, PR, Brasil
}

\begin{abstract}
Spatial variability of chemical attributes in soils tends to increase under the no-tillage system. However, data regarding this variability under this system for a long time are scarce. This study aimed to evaluate the spatial variability of phosphorus $(\mathrm{P})$, organic matter $(\mathrm{OM}), \mathrm{pH}$, aluminum $(\mathrm{Al})$, calcium $(\mathrm{Ca})$, magnesium $(\mathrm{Mg})$, potassium $(\mathrm{K})$, base saturation $(\mathrm{V} \%)$, sulfur $\left(\mathrm{SO}_{4}{ }^{2-}\right)$, and micronutrients: boron $(\mathrm{B})$, iron $(\mathrm{Fe})$, copper $(\mathrm{Cu})$, manganese $(\mathrm{Mn})$, and zinc $(\mathrm{Zn})$ in soil with conventional tillage and no-tillage treatments for more than three decades in order to optimize fertilization and maintain soil conservation. Samples of Rhodic Hapludox were collected at $0.00-0.20 \mathrm{~m}$ depth. Sampling points were spaced $5 \mathrm{~m}$ apart, totaling 100 points. All sampling points were georeferenced according to the tillage system. Samples were analyzed chemically. Semivariograms and kriging were used in descriptive statistics and geostatistics analyses of the results. Only micronutrients and $\mathrm{P}$ presented distinct spatial variability between the treatments. Most of the analyzed chemical attributes presented spatial dependency in both tillage systems, which may help determine the best form of sampling and indicate adequate fertilization. According to semivariogram range values of $\mathrm{OM}, \mathrm{Mg}$, and $\mathrm{K}$, the same sampling strategy may be adopted for analysis in both tillage systems, yet for $\mathrm{Al}, \mathrm{Ca}$, and $\mathrm{pH}$ the strategy should be specific.
\end{abstract}

KEYWORDS: Fertility. Geostatistics. Soil tillage.

\section{INTRODUCTION}

The knowledge of the spatial variability of soil chemical attributes in farmland soils helps develop more rational and cost-effective fertilization programs, enhance yields, and lower environmental impacts. Furthermore, the time length of a tillage system in a field, which is a very important factor affecting soil chemical attributes, may help predict the effect of the adopted tillage system on soil fertility and productivity.

Geostatistics focuses on the spatial variability of soil nutrient levels in specific areas represented by isoline maps. Models of spatial distributions have shown that the range varies among soil attributes (DALCHIAVON et al., 2012; ARTUR et al., 2014) and tillage systems (VIEIRA et al., 2011; NEGREIROS NETO et al., 2014). Such models help optimize fertilization without harming the environment and the natural resources on which they originate.

Soil degradation has an increasingly negative impact on food production and the environment due to its extent and intensity. Soil quality indicates responses to the adopted tillage system through changes in nutrient availability and organic matter content (ALLEN et al., 2011). Thus, research should focus on soil tillage systems and sampling methods that improve soil quality in the long term.

In areas where not all biomass is removed, there is a trend towards a higher concentration of some chemical elements, which may form spots in the soil. On such fields, it is not possible to find a spatial dependency function that can be used for mapping (MACIEL et al., 2012). However, over time, they tend to disappear and become less variable (ANGHINONI; SALET, 1998).

For example, a cultivation of sugarcane on the same field for more than 30 years demonstrated high range values of chemical attributes in the 0.00 $0.20 \mathrm{~m}$ soil layer, which was attributed to a longterm weathering period of the surface layers and/or fertilization (MARQUES JÚNIOR et al., 2008). However, Guedes Filho et al., 2010 reported high yield variability under the no-tillage system for a long time and uncontrollable conditions such as 
irregular rainfall distribution.

Crop rotation on the same field with different row spacings and fertilization bands that almost never coincide suggest the hypothesis that a long-term no-tillage system may present a lower variability than a short-term no-tillage system (ANGHINONI; SALET, 1998).

Consequently, the objective of this work was to evaluate the spatial variability of soil chemical attributes with semivariograms by analyzing the spatial dependency of sampled points in reference areas under no-tillage and conventional tillage systems for more than three decades.

\section{MATERIAL AND METHODS}

The experimental area is situated in the municipality of Ponta Grossa, PR, Brazil. It is characterized by an annual average temperature of less than $21^{\circ} \mathrm{C}$ and the total annual rainfall of 1300 $1800 \mathrm{~mm}$ well distributed throughout the year (CAVIGLIONE et al.; 2000).

The soil, classified as Latossolo Vermelho distrófico (Santos et al., 2014) equivalent to the Rhodic Hapludox of the USDA soil classification (Soil Survey Staff, 2010), contains $680 \mathrm{~g} \mathrm{~kg}^{-1}$ clay and has been under no-tillage and conventional tillage since 1981. The conventional tillage system consists of soil preparation with the plow ( $\varnothing 0.60$ $\mathrm{m})$ after the harvest of the summer crop and another preparation to the depth of $0.20 \mathrm{~m}$ after the harvest of the winter crop, followed by two harrowings $(\varnothing$ $0.40 \mathrm{~m}$ ).

Experimental plots have been subjected to crop rotation with soybean (Glycine max (L.) Merrill) and maize (Zea mays L.) in the summer and oat (Avena strigosa) and hairy vetch (Vicia villosa Roth) in the winter since 1995. Crop rotation previous to the one presented above is described in Merten (1995).

The experimental plots had dimensions of $100 \times 50 \mathrm{~m}$ under the conventional tillage system and $100 \times 100 \mathrm{~m}$ under the no-tillage system, and a slope of 6.9 and $8.1 \%$, respectively. The soil sampling grid consisted of a $50 \times 50 \mathrm{~m}$ plot with spacing $5 \mathrm{~m}$ between sampling points, totaling 100 points sampled under each system. According to Souza \& Souza (2014), variograms with more than 100 sampled points do not differ from variograms with 100 points, and variograms with a lower number of points produce a kriging estimation error.

Soil sampling was carried out in September 2013 at $0.00-0.20 \mathrm{~m}$ depth using the Dutch auger. All sampled points were georeferenced. The following chemical attributes were analyzed: $\mathrm{pH}$
$\left(\mathrm{CaCl}_{2}\right) ; \mathrm{P}$ and $\mathrm{K}$ (Mehlich-1); exchangeable $\mathrm{Ca}$, $\mathrm{Mg}$, and $\mathrm{Al}\left(\mathrm{KCl} 1 \mathrm{~mol} \mathrm{~L}^{-1}\right) ; \mathrm{SO}_{4}{ }^{2-}\left[\mathrm{Ca}\left(\mathrm{H}_{2} \mathrm{PO}_{4}\right)_{2}\right.$, $500 \mathrm{mg} \mathrm{L}^{-1}$ of $\mathrm{P}$ in HOAc $2 \mathrm{mols} \mathrm{L}^{-1}$ ]; OM (Walkley Black); and base saturation (V\%) according to the methodology described by Pavan et al. (1992); and micronutrients: $\mathrm{B}$ (hot water); $\mathrm{Fe}, \mathrm{Cu}, \mathrm{Mn}$, and $\mathrm{Zn}$ (Mehlich-1) following the methodology of Silva (1999).

Outliers were excluded from the data set when analyzed by the Action tool. Statistical analyzes were performed using the GS + program (Gamma Design Software, 2000).

Using descriptive statistics, the following parameters of the collected data were evaluated: mean, standard deviation, maximum value, minimum value, variation coefficients, asymmetry, and kurtosis. Geostatistical analyses of the spatial variability of the attributes were carried out according to the methodology proposed by Vieira et al. (1983). Spatial dependency among the samples was determined by fitting the experimental semivariance to the best mathematical model using the highest coefficient of determination $\left(\mathrm{R}^{2}\right)$, the lowest sum of residual squares (SQR), and crossvalidation. Spherical, exponential, linear, and Gaussian models were tested.

Semivariograms graphically represent semivariance as a function of a given distance (h) and provide: $C_{0}$ : the nugget effect; $C_{1}$ : structural variance, and $a$ : range. The ratio of spatial dependency among the samples is given by the ratio between the nugget and sill $\left(\mathrm{C}_{0}+\mathrm{C}_{1}\right)$, classified according to Cambardella et al. (1994).

For variables that presented a tendency to compromise the fitting in a semivariogram and the consequent result of the analysis, the trend was withdrawn as suggested by Vieira et al. (1983). Residual values allowed for a better fitting in the semivariograms, directing them to become stationary. These values were later added to the interpolated data for map generation.

Based on spatial dependency models revealed by semivariograms, values for nonsampled sites were estimated considering that the area comprising the range stipulated by the semivariogram has similar values. Thus, maps of isolines were generated using the kriging interpolation technique according to semivariogram parameters without trend.

For variables that did not present spatial dependency, the inverse method of a square distance was used, since the kriging method did not show any difference for soil attributes (SOUZA et al., 2010).

Following specific classifications of each 
nutrient, isoline maps were elaborated according to the interpreted levels of soil chemical attributes. Concerning $\mathrm{SO}_{4}{ }^{2-}$ levels, the classification was done according to Raij et al. (1997) and micronutrient levels according to Alvarez et al. (1999).

\section{RESULTS AND DISCUSSION}

Descriptive statistics (Table 1) helped independently evaluate the general behavior of the attributes in space and visualize trends and dispersion parameters of the data that may contribute to geostatistical analysis.

Values of asymmetry and kurtosis, which help draw inferences about the frequency distribution of the data set, showed that $\mathrm{Cu}, \mathrm{Mn}$, and Zn did not have a normal distribution and displayed differences between the tillage systems. As for the remaining attributes, there was a tendency for a normal distribution, similar to that found in the conventional tillage system by Machado et al. (2007) and in the no-tillage system by Negreiros Neto et al. (2014).

Similarly, Vian et al. (2012) did not find a normal frequency distribution of soil micronutrient contents. However, Webster \& Oliver (2007) mention that in geostatistics, although not always, the normality of the data set enables a prediction of values not sampled.

Table 1. Descriptive statistics of chemical attributes of Dystrophic Red Latosol at $0.00-0.20 \mathrm{~m}$ depth under no-tillage and conventional tillage systems.

\begin{tabular}{|c|c|c|c|c|c|c|c|}
\hline Content in soil & Mean & $\begin{array}{r}\text { Standard } \\
\text { deviation }\end{array}$ & Minimum & Maximum & $\mathrm{CV} \%$ & Asymmetry & Kurtosis \\
\hline \multicolumn{8}{|c|}{ Conventional tillage system } \\
\hline $\mathrm{P}^{(1)}, \mathrm{mg} \mathrm{dm}^{3}$ & 4.30 & 1.38 & 1.90 & 8.70 & 32 & 0.03 & -0.25 \\
\hline $\mathrm{MO}^{(2)}, \mathrm{g} \mathrm{dm}^{-3}$ & 45.90 & 2.90 & 37.60 & 53.70 & 6 & -0.26 & 0.33 \\
\hline $\mathrm{pH}^{(3)}$ & 4.15 & 0.13 & 3.90 & 4.40 & 3 & 0.03 & -0.79 \\
\hline $\mathrm{Al}^{(4)}, \mathrm{cmol}_{\mathrm{c}} \mathrm{dm}^{-3}$ & 0.92 & 0.38 & 0.24 & 1.83 & 41 & 0.26 & -0.81 \\
\hline $\mathrm{Ca}^{(4)}, \mathrm{cmol}_{\mathrm{c}} \mathrm{dm}^{-3}$ & 2.50 & 0.54 & 1.33 & 3.52 & 22 & -0.32 & -0.81 \\
\hline $\mathrm{Mg}^{(4)}, \mathrm{cmol}_{\mathrm{c}} \mathrm{dm}^{-3}$ & 1.26 & 0.29 & 0.67 & 1.88 & 23 & -0.18 & -0.76 \\
\hline $\mathrm{K}^{(\mathrm{I})}, \mathrm{cmol}_{\mathrm{c}} \mathrm{dm}^{-3}$ & 0.12 & 0.03 & 0.07 & 0.22 & 25 & 0.11 & 0.11 \\
\hline $\mathrm{V}, \%$ & 26.00 & 5.37 & 14.00 & 35.00 & 21 & -0.47 & -0.82 \\
\hline $\mathrm{SO}_{4}{ }^{2-(5)}, \mathrm{mg} \mathrm{dm}^{-3}$ & 5.84 & 2.46 & 1.18 & 12.34 & 42 & 0.23 & -0.57 \\
\hline $\mathrm{B}^{(6)}, \mathrm{mg} \mathrm{dm}^{-3}$ & 0.87 & 0.08 & 0.70 & 1.09 & 9 & 0.27 & -0.49 \\
\hline $\mathrm{Fe}^{(1)}, \mathrm{mg} \mathrm{dm}^{-3}$ & 67.00 & 10.49 & 44.98 & 89.61 & 16 & 0.30 & -0.92 \\
\hline $\mathrm{Cu}^{(1)}, \mathrm{mg} \mathrm{dm}^{-3}$ & 2.66 & 0.28 & 1.80 & 3.66 & 11 & 1.01 & 3.63 \\
\hline $\mathrm{Mn}^{(1)}, \mathrm{mg} \mathrm{dm}^{-3}$ & 41.30 & 6.86 & 25.55 & 69.21 & 17 & 2.21 & 5.39 \\
\hline $\mathrm{Zn}^{(1)}, \mathrm{mg} \mathrm{dm}^{-3}$ & 2.26 & 3.11 & 0.81 & 18.28 & 138 & 3.98 & 15.76 \\
\hline \multicolumn{8}{|c|}{ No-tillage system } \\
\hline $\mathrm{P}, \mathrm{mg} \mathrm{dm^{-3 }}$ & 9.27 & 7.04 & 2.30 & 32.60 & 76 & 0.52 & -0.31 \\
\hline $\mathrm{MO}, \mathrm{g} \mathrm{dm}^{-3}$ & 49.00 & 3.12 & 41.63 & 56.41 & 6 & -0.01 & -0.04 \\
\hline $\mathrm{pH}$ & 4.04 & 0.18 & 3.70 & 4.60 & 4 & 0.88 & 0.42 \\
\hline $\mathrm{Al}, \mathrm{cmol}_{\mathrm{c}} \mathrm{dm}^{-3}$ & 1.02 & 0.51 & 0.04 & 2.31 & 50 & 0.09 & -0.46 \\
\hline $\mathrm{Ca}, \mathrm{cmol}_{\mathrm{c}} \mathrm{dm}^{-3}$ & 2.50 & 0.81 & 1.04 & 4.95 & 32 & 0.80 & 0.27 \\
\hline $\mathrm{Mg}, \mathrm{cmol}_{\mathrm{c}} \mathrm{dm}^{-3}$ & 1.16 & 0.38 & 0.50 & 2.27 & 33 & 0.79 & 0.35 \\
\hline $\mathrm{K}, \mathrm{cmol}_{\mathrm{c}} \mathrm{dm}^{-3}$ & 0.14 & 0.03 & 0.09 & 0.24 & 21 & 0.57 & 0.02 \\
\hline $\mathrm{V}, \%$ & 22.60 & 7.09 & 9.43 & 44.82 & 31 & 0.92 & 0.58 \\
\hline $\mathrm{SO}_{4}{ }^{2-}, \mathrm{mg} \mathrm{dm}^{-3}$ & 5.50 & 2.70 & 0.69 & 13.12 & 49 & 0.34 & -0.28 \\
\hline $\mathrm{B}, \mathrm{mg} \mathrm{dm}^{-3}$ & 0.90 & 0.06 & 0.77 & 1.06 & 7 & 0.23 & -0.32 \\
\hline $\mathrm{Fe}, \mathrm{mg} \mathrm{dm}^{-3}$ & 70.70 & 28.00 & 18.81 & 128.35 & 40 & 0.34 & -0.78 \\
\hline $\mathrm{Cu}, \mathrm{mg} \mathrm{dm}^{-3}$ & 4.93 & 2.57 & 2.09 & 14.00 & 52 & 2.10 & 4.10 \\
\hline $\mathrm{Mn}, \mathrm{mg} \mathrm{dm}^{-3}$ & 92.40 & 92.00 & 14.79 & 417.97 & 100 & 1.31 & 0.97 \\
\hline $\mathrm{Zn}, \mathrm{mg} \mathrm{dm}^{-3}$ & 2.40 & 2.30 & 0.54 & 11.57 & 96 & 2.53 & 5.76 \\
\hline
\end{tabular}

Extractors: ${ }^{(1)}$ Mehlich-1; ${ }^{(2)}$ Walkey Black; ${ }^{(3)} \mathrm{CaCl}_{2} ;{ }^{(4)} \mathrm{KCL} 1 \mathrm{~mol} \mathrm{~L}^{-1} ;{ }^{(5)} \mathrm{Ca}\left(\mathrm{H}_{2} \mathrm{PO}_{4}\right)_{2}, 500 \mathrm{~mol} \mathrm{~L}^{-1}$ of P in $\mathrm{HOAc} 2 \mathrm{~mol} \mathrm{~L}^{-1} ;{ }^{(6)} \mathrm{Hot}$ water.

Despite presenting low $\mathrm{pH}$ and base saturation values, soil on the experimental site has good fertility (Table 1). Soil tillage only influenced $\mathrm{P}$ levels, which demonstrated average levels under 
the no-tillage and low levels under the conventional system, thus corroborating data found by Leite et al. (2010). The remaining chemical attributes showed the same classification for both tillage systems, ranging from average to high and very high.

For Zanão Júnior et al. (2010), high levels of $\mathrm{Mn}$ and $\mathrm{Zn}$ in the $0-0.10 \mathrm{~m}$ layer of the no-tillage system may be explained by a high amount of organic matter, which is one of the main sources of these nutrients.

The longer the soil remains under a conservation system, the higher is the content of organic matter (SCHLINDWEIN; ANGHINONI, 2000). However, although the results prove that the same situation may occur in a conventional system in the long term, one must take into the account climate conditions and soil texture that favor a slower decomposition of OM. Furthermore, a long time span of cultivation with the conventional tillage system, crop rotation, and cover plants also contributes greatly to high OM content in the soil.

Based on the classification criteria proposed by Warrick \& Nielsen (1980), only OM and pH presented a low coefficient of variation $(\mathrm{CV})$ for both tillage systems with values of $6 \%$ for $\mathrm{OM}$ and 3 to $4 \%$ for $\mathrm{pH}$. As these are the main indicators of soil quality, it is valid to consider these results in the analysis of the longevity of soil tillage.

Phosphorus presented a high coefficient of variation $(76 \%)$ under the no-tillage system, while other attributes behaved in a similar manner under both tillage systems, having a mean coefficient of variation. According to Falleiro et al. (2003), less mobile elements in the soil such as $\mathrm{P}$ in general form higher concentration gradients.

Regarding micronutrients, the highest variation was observed for $\mathrm{Zn}$ and the lowest for $\mathrm{B}$ in both treatments. $\mathrm{Fe}, \mathrm{Cu}$, and $\mathrm{Mn}$ showed a significantly higher coefficient of variation in the no-tillage system compared to the conventional system, but according to the classification, the management systems differed only for $\mathrm{Cu}$ and $\mathrm{Mn}$.

Semivariogram parameters presented in Table 2 show spatial dependency of the studied chemical attributes in both management systems, with the exception of $\mathrm{P}$ and $\mathrm{SO}_{4}{ }^{2-}$ in both systems and $\mathrm{V} \%$ in the no-tillage system, which followed a pure nugget effect model (Epp), that is the variable is considered spatially independent (CAVALCANTE et al., 2007).

Different results were observed for micronutrients in both tillage systems. Only B demonstrated Epp in the conventional system and spatial dependency in the no-tillage system. Other nutrients were inversely proportional, presenting dependency in the conventional system and Epp in the no-tillage system. This demonstrates a distinct spatial behavior of micronutrients in both tillage systems. The predominance of structured models in the conventional tillage system may be associated with periodic soil revolving, mainly because it usually occurs at very low levels in the soil.

The best fitting models for the semivariograms were spherical and exponential, which according to Cavalcante et al. (2007) are the most common to fit soil variables.

The nugget effect in both tillage systems for $\mathrm{K}, \mathrm{pH}, \mathrm{Mg}$, and $\mathrm{B}$ was low when compared to the other elements. This is justified by a larger spatial continuity of these attributes (Table 2).

The range is evaluated in a semivariogram because it indicates the maximum distance at which sample points are correlated (VIEIRA et al., 1983). It may be used to define the spacing for sample collection (SOUZA et al., 1997). As shown in Table 2, the range for $\mathrm{OM}, \mathrm{Mg}$, and $\mathrm{K}$ displayed little difference between treatments, with a slight tendency towards a larger distance in the no-tillage system. However, $\mathrm{Al}, \mathrm{Ca}$, and mainly $\mathrm{pH}$ reached wider range in the conventional tillage system (26, 20 , and $31 \mathrm{~m}$ ) against 16,13 , and $9 \mathrm{~m}$ in the notillage system.

The largest distance observed for micronutrients was $28 \mathrm{~m}$ for $\mathrm{Zn}$ and the lowest $11 \mathrm{~m}$ for $\mathrm{Cu}$ in the conventional tillage system. The low range variation between the variables, which is essential in the determination of sample spacing, demonstrates the sensitivity of micronutrient presence to space. According to Zonta et al. (2014), the minimum number and the quality of soil subsamples by means of denser sampling guarantees a more representative sample grid of all soil attributes. It was not possible to assign a range for the variables with Epp.

For attributes that present dependency, geostatistics helps establish the number of soil samples to be collected according to the range, tillage system, and attributes to be analyzed (MCBRATNEY; WEBSTER, 1983; SOUZA et al., 1997). 
Table 2. Semivariance parameters and spatial dependency classification of chemical attributes of Dystrophic Red Latosol at $0.00-0.20 \mathrm{~m}$ depth under no-tillage and conventional tillage systems.

\begin{tabular}{lcccccc}
\hline Content in soil & $\mathrm{C}_{0}{ }^{(1)}$ & $\mathrm{C}_{1}+\mathrm{C}_{0}{ }^{(2)}$ & $\mathrm{A}^{(3)}(\mathrm{m})$ & Model & $\mathrm{RD}^{(4)}(\%)$ & $\begin{array}{c}\text { Dependency } \\
\text { classificatio }\end{array}$ \\
\hline $\mathrm{P}, \mathrm{mg} \mathrm{dm}^{-3}$ & 0.6900 & 0.690 & - & $\begin{array}{c}\text { Conventional tillage system } \\
\text { Exponential }\end{array}$ & - & - \\
$\mathrm{MO}, \mathrm{g} \mathrm{dm}^{-3}$ & 0.4100 & 7.100 & 8 & 6 & Strong \\
$\mathrm{pH}$ & 0.0030 & 0.008 & 31 & Spherical & 37 & Moderate \\
$\mathrm{Al}, \mathrm{cmol}_{\mathrm{c}} \mathrm{dm}^{-3}$ & 0.0070 & 0.050 & 26 & Spherical & 14 & Strong \\
$\mathrm{Ca}, \mathrm{cmol}_{\mathrm{c}} \mathrm{dm}^{-3}$ & 0.0200 & 0.100 & 20 & Spherical & 20 & Strong \\
$\mathrm{Mg}, \mathrm{cmol}_{\mathrm{c}} \mathrm{dm}^{-3}$ & 0.0030 & 0.040 & 9 & Spherical & 7 & Strong \\
$\mathrm{K}, \mathrm{cmol}_{\mathrm{c} \mathrm{dm}}{ }^{-3}$ & 0.0001 & 0.055 & 12 & Spherical & 0 & Strong \\
$\mathrm{V}, \%$ & 1.5000 & 8.690 & 24 & Exponential & 17 & Strong \\
$\mathrm{SO}_{4}{ }^{2-}, \mathrm{mg} \mathrm{dm}^{-3}$ & 6.2400 & 6.240 & - & Epp & - & - \\
$\mathrm{B}, \mathrm{mg} \mathrm{dm}^{-3}$ & 0.0060 & 0.006 & - & Epp & - & - \\
$\mathrm{Fe}, \mathrm{mg} \mathrm{dm}^{-3}$ & 40.8000 & 81.610 & 19 & Spherical & 50 & Moderate \\
$\mathrm{Cu}, \mathrm{mg} \mathrm{dm}^{-3}$ & 0.0001 & 0.051 & 11 & Exponential & 0 & Strong \\
$\mathrm{Mn}, \mathrm{mg} \mathrm{dm}^{-3}$ & 5.6900 & 15.930 & 15 & Gaussian & 36 & Moderate \\
$\mathrm{Zn}, \mathrm{mg} \mathrm{dm}^{-3}$ & 3.6200 & 5.710 & 28 & Linear & 63 & Moderate
\end{tabular}

\section{$\mathrm{P}, \mathrm{mg} \mathrm{dm} \mathrm{m}^{-3}$ \\ $\mathrm{MO}, \mathrm{g} \mathrm{dm}^{-3}$ \\ $\mathrm{pH}$}

$\mathrm{Al}, \mathrm{cmol}_{\mathrm{c}} \mathrm{dm}^{-3}$

$\mathrm{Ca}, \mathrm{cmol}_{\mathrm{c}} \mathrm{dm}^{-3}$

$\mathrm{Mg}, \mathrm{cmol}_{\mathrm{c}} \mathrm{dm}^{-3}$

$\mathrm{K}, \mathrm{cmol}_{\mathrm{c}} \mathrm{dm}^{-3}$

$\mathrm{V}, \%$

$\mathrm{SO}_{4}{ }^{2-}, \mathrm{mg} \mathrm{kg}^{-1}$

$\mathrm{B}, \mathrm{mg} \mathrm{dm}^{-3}$

$\mathrm{Fe}, \mathrm{mg} \mathrm{dm}^{-3}$

$\mathrm{Cu}, \mathrm{mg} \mathrm{dm}^{-3}$

$\mathrm{Mn}, \mathrm{mg} \mathrm{dm}^{-3}$

$\mathrm{Zn}, \mathrm{mg} \mathrm{dm}^{-3}$

${ }^{(1)} \mathrm{C}_{0}$ : nugget effect; ${ }^{(2)} \mathrm{C}_{0}+\mathrm{C}_{1}$ : still; ${ }^{(3)} \mathrm{A}$ : range;

\subsection{0 \\ 0.8900}

0.0008

0.1100

0.0400

0.0060

0.0003

47.5300

8.5800

0.0020

854.0800

6.7400

8700.0000

0.4300
No-tillage system

$0.410 \quad-\quad$ Epp

$\begin{array}{ll}7.990 & 10\end{array}$

$\begin{array}{ll}0.030 & 9\end{array}$

$0.220 \quad 16$

$0.090 \quad 13$

$0.100 \quad 11$

$0.001 \quad 15$

0.001
47.530

8.580

0.004

854.080

6.740

8700.000

0.430

Epp
Exponential

Exponential

Spherical

Spherical

Exponential

Spherical

Epp

Epp

Spherical

Epp

Epp

Epp
According to Cambardella et al. (1994), the degree of spatial dependency was classified as strong and moderate by the proportion of a random component $\left(\mathrm{C}_{0}\right)$ to total variance $\left(\mathrm{C}_{0}+\mathrm{C}_{1}\right)$. These dependency characteristics may reflect the tillage system as well as the long-term effect.

The study of spatial variability shows differences in the behavior of soil elements according to the tillage system and the nutrient, differences which the classic statistics does not detect. Isoline maps, obtained through the interpolation of data, help visualize the spatial distribution of nutrient contents in the sampled area and plan the distribution of nutrients in precision farming.

Figures 1, 2, and 3 shows the distribution of nutrients according to soil level interpretation classes: very low, low, average, high, and very high.
According to Zanão Júnior et al. (2010), generating maps according to soil fertility classes for each state or region is more logical than according to programs that generate them. This way fertilizers may be applied more accurately and cheaply.

Isoline maps for $\mathrm{OM}$ and $\mathrm{pH}$ were more homogeneous presenting low $\mathrm{CV}$, as opposed to $\mathrm{P}$, $\mathrm{SO}_{4}{ }^{2-}$, and $\mathrm{Al}$ that demonstrated larger heterogeneity (Figures 1 and 2). However, they became references for liming and fertilization recommendations and for the collection of soil samples to evaluate soil fertility. 


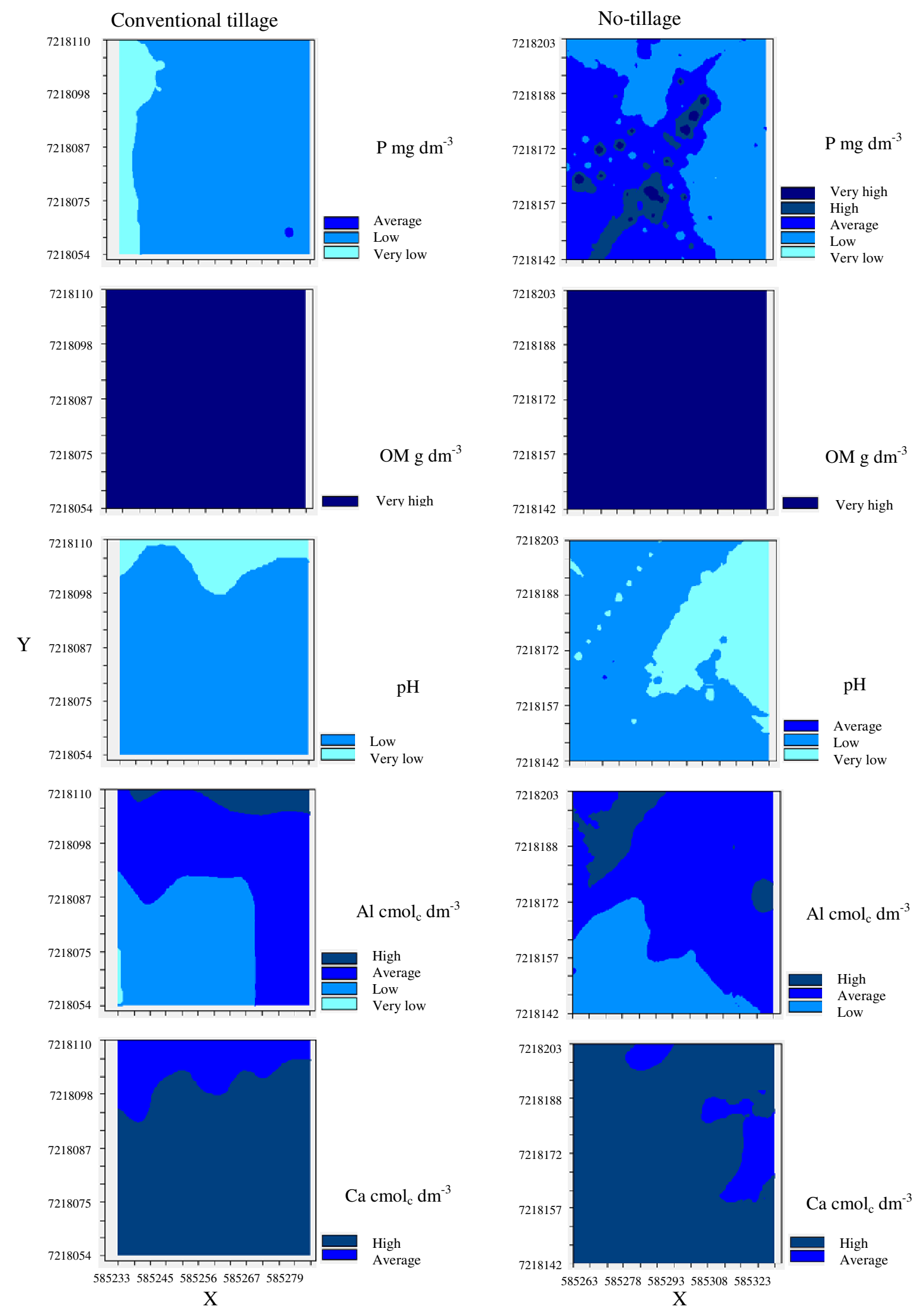

Figure 1. Isoline maps based on classes of $\mathrm{P}, \mathrm{MO}, \mathrm{pH}, \mathrm{Al}$, and $\mathrm{Ca}$ contents in the $0.00-0.20 \mathrm{~m}$ soil layer under no-tillage and conventional systems for a long time in Ponta Grossa, PR, Brazil. 

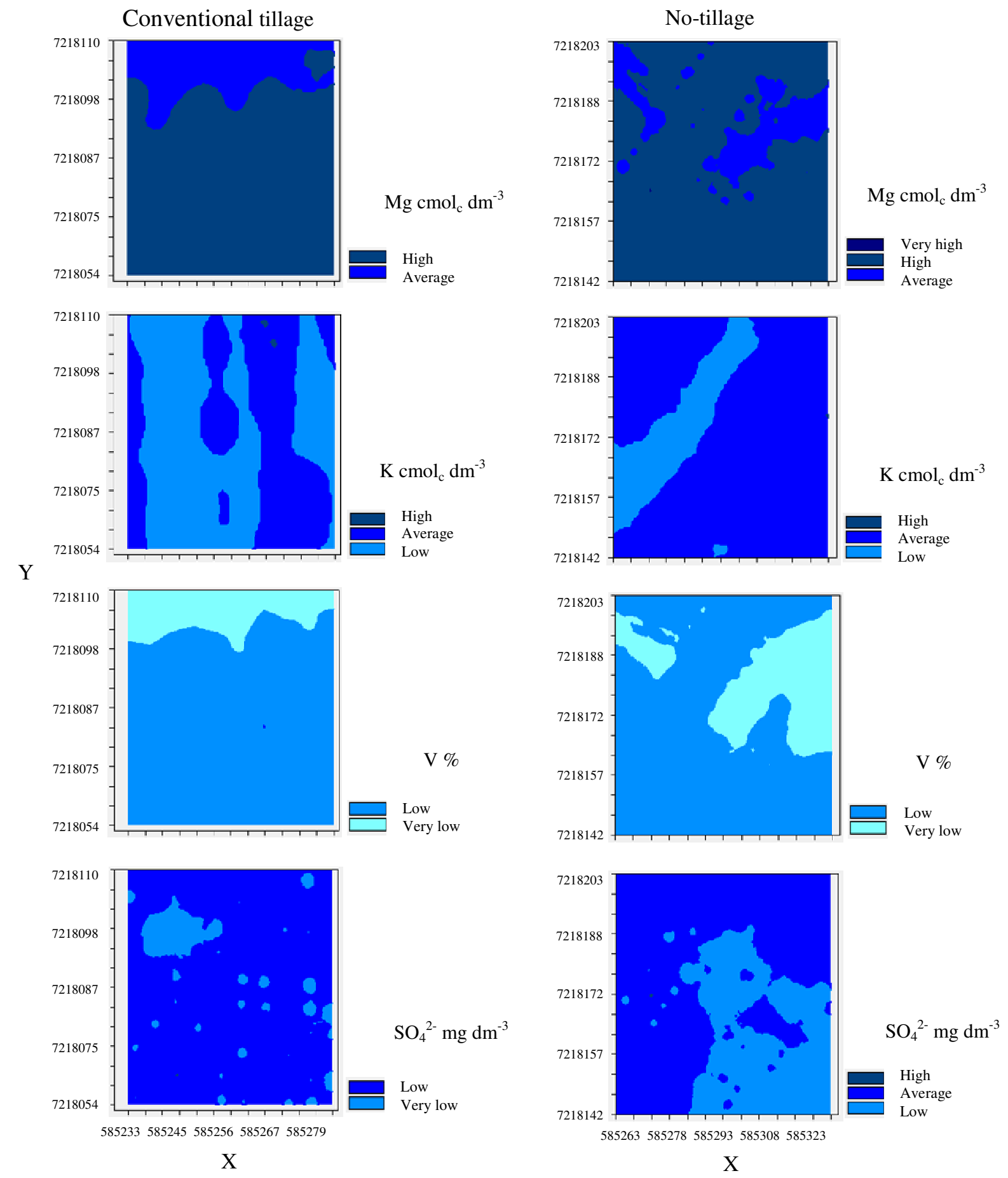

Figure 2. Isoline maps based on classes of $\mathrm{Mg}, \mathrm{K}, \mathrm{V} \%$, and $\mathrm{SO}_{4}{ }^{2-}$ in the $0.00-0.20 \mathrm{~m}$ soil layer under no-tillage and conventional systems for a long time in Ponta Grossa, PR, Brazil. 

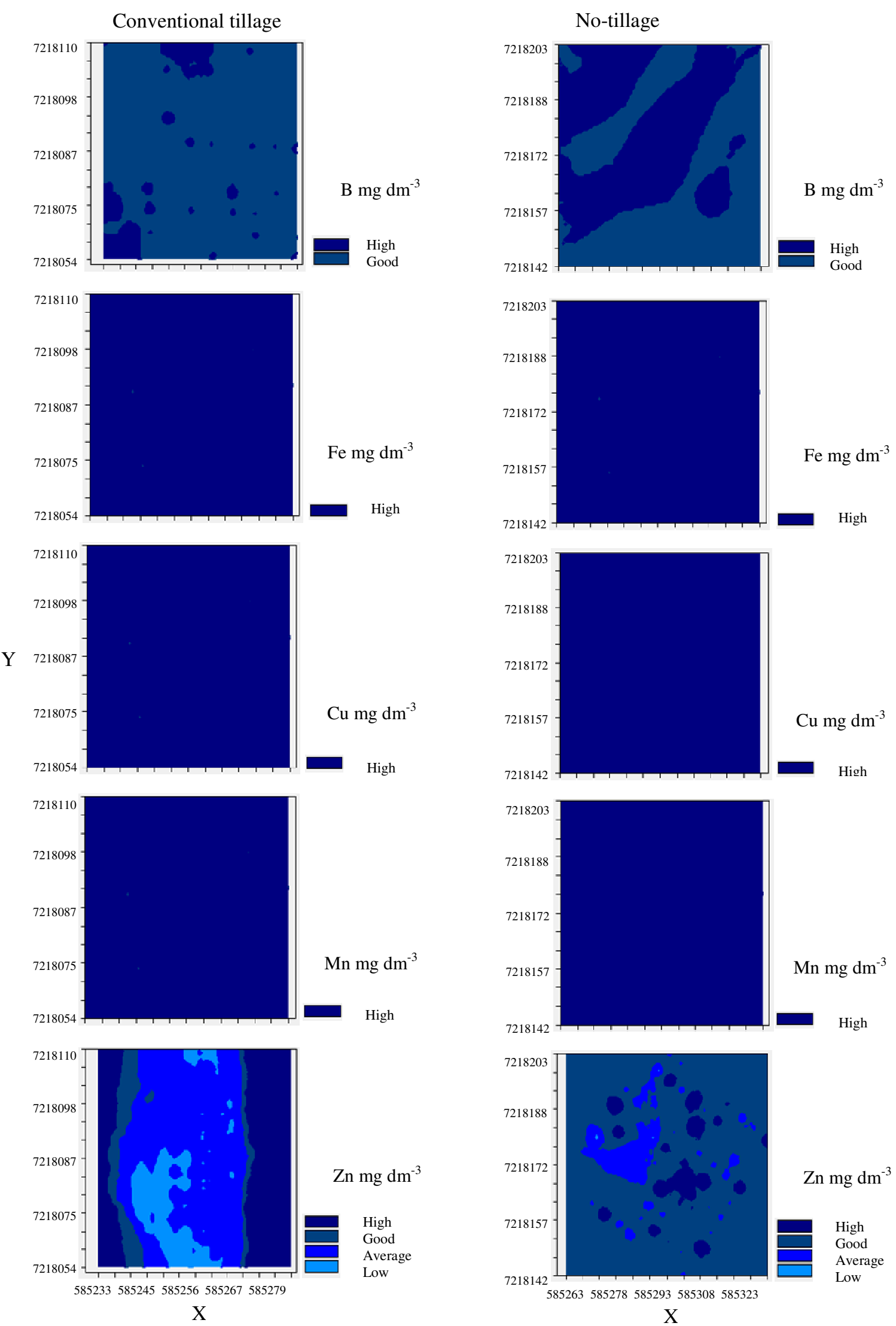
Regarding micronutrients (Figure 3), the maps showed that soils under both systems adopted for a long time do not display a concentration difference for $\mathrm{Fe}, \mathrm{Cu}$, and $\mathrm{Mn}$. However, $\mathrm{B}$ and $\mathrm{Zn}$ differed between treatments; $\mathrm{Zn}$ followed a positive trend and $\mathrm{B}$ a slightly negative trend in the notillage system. Therefore, it is reasonable to establish that the no-tillage system does not prejudice the spatial distribution of micronutrients in relation to the conventional tillage system.

\section{CONCLUSIONS}

Of all attributes analyzed in this work, only $\mathrm{P}, \mathrm{B}$, and $\mathrm{Zn}$ presented spatial variability between the tillage systems in the long term. For these nutrients, the no-tillage system provided larger spatial variability than the conventional tillage system.

Most of the chemical attributes presented spatial dependency in both tillage systems, which may determine the best form of sampling and indicate adequate fertilization.

According to the range values for $\mathrm{OM}, \mathrm{Mg}$, and $\mathrm{K}$ in the semivariograms, the same sampling strategy may be adopted for analysis in both tillage systems, yet for $\mathrm{Al}, \mathrm{Ca}$, and $\mathrm{pH}$ the strategy should be specific.

RESUMO: A variabilidade espacial dos atributos químicos tende a aumentar em solos sob sistema plantio direto. No entanto faltam informações sobre essa variabilidade em solos submetidos a esse sistema por longo período. Este estudo objetivou avaliar a variabilidade espacial do fósforo (P), matéria orgânica (MO), $\mathrm{pH}$, alumínio $(\mathrm{Al})$, cálcio $(\mathrm{Ca})$, magnésio $(\mathrm{Mg})$, potássio $(\mathrm{K})$, saturação por bases $(\mathrm{V} \%)$, enxofre (SO42-) e dos micronutrientes boro $(\mathrm{B})$, ferro $(\mathrm{Fe})$, cobre $(\mathrm{Cu})$, manganês $(\mathrm{Mn})$ e zinco $(\mathrm{Zn})$ em plantio direto e plantio convencional adotados há mais de três décadas, como forma de otimizar a aplicação de fertilizantes e preservar a adoção do manejo conservacionista. Amostras de Latossolo Vermelho distrófico coletadas na profundidade de $0,00-0,20 \mathrm{~m}$, e $5 \mathrm{~m}$ de distância entre os 100 pontos amostrados e georreferenciados por manejo, foram analisadas quimicamente e os resultados submetidos à estatística descritiva e à geoestatística, através do estudo de semivariogramas e krigagem. Apenas os micronutrientes e o $\mathrm{P}$ apresentaram variabilidade espacial distinta entre os manejos. A maioria dos atributos químicos estudados apresentou dependência espacial em ambos os sistemas de manejo, o que pode determinar a melhor forma de amostragem e indicar a adubação adequada. De acordo com os alcances atribuídos aos semivariogramas, para MO, Mg e K pode-se adotar a mesma estratégia de amostragem para análise em ambos sistemas de manejo e para $\mathrm{Al}, \mathrm{Ca}$ e $\mathrm{pH}$ deve ser específica

PALAVRAS-CHAVE: Fertilidade. Geoestatística. Solo-manejo.

\section{REFERENCES}

ALLEN, D. E.; SINGH, B. P.; DALAL, R. C. Soil health indicators under climate change: a review of current knowledge. In: SINGH, B. P.; COWIE, A. L.; CHAN, K. Y. (Eds.). Soil Health and Climate Change. Berlin: Springer-Verlag, 2011. p. 25-45. https://doi.org/10.1007/978-3-642-20256-8_2

ALVAREZ V, V. H.; NOVAIS, R, F.; BARROS, N. F.; CATARUTTI, R. B.; LOPES, A. S. Interpretação dos resultados das análises de solos. In: RIBEIRO, A. C.; GUIMARÃES, P. T. G.; ALVAREZ V, V. H.

Recomendações para o uso de corretivos e fertilizantes em Minas Gerais. $5^{\text {a }}$ Aproximação. Viçosa: Comissão de Fertilidade do Solo do Estado de Minas Gerais, 1999. p. 25-32.

ANGHINONI, I.; SALET, R. L. Amostragem do solo e as recomendações de adubação e calagem no sistema plantio direto. In: NUERNBERG, N. J. Conceitos e fundamentos do sistema plantio direto. Lages: Núcleo Regional Sul/Sociedade Brasileira de Ciência do Solo, 1998. p. 27-52.

ARTUR, A. G.; OLIVEIRA, D. P.; COSTA, M. C. G.; ROMERO, R. E.; SILVA, M. V. C.; FERREIRA, T. O. Variabilidade espacial dos atributos químicos do solo, associada ao microrrelevo. Revista Brasileira de

Engenharia Agrícola e Ambiental, v. 18, n. 2, p. 141-149, 2014. https://doi.org/10.1590/S141543662014000200003 
CAMBARDELLA, C. A.; MOORMAN, T. B.; NOVAK, J. M.; PARKIN, T. B.; KARLEN, D. L.; TURCO, R. F.; KONOPKA, A. E. Field-scale variability of soil properties in central Iowa soils. Soil Science Society of America Journal, v. 58, n. 5, p. 1501-1511, 1994. https://doi.org/10.2136/sssaj1994.03615995005800050033x

CAVAlCANTE, E. G. S.; ALVES, M. C.; SOUZA, Z. M.; PEREIRA, G. T. Variabilidade espacial de atributos químicos do solo sob diferentes usos e manejos. Revista Brasileira de Ciência do Solo, v. 31, n. 6, p. 1329-1339, 2007. https://doi.org/10.1590/S0100-06832007000600012

CAVIGLIONE, J. H.; KIIHL, L. R. B.; CARAMORI, P. H.; OLIVEIRA, D. Cartas climáticas do Paraná, Londrina: Instituto Agronômico do Paraná, 2000. CD ROM.

DALCHIAVON, F. C.; CARVALHO, M. P.; ANDREOTTI, M.; MONTANARI, R. Variabilidade espacial de atributos da fertilidade de um Latossolo Vermelho distroférrico sob sistema plantio direto. Revista Ciência Agronômica, v. 43, n. 3, p. 453-461, 2012. https://doi.org/10.1590/S1806-66902012000300006

FALLEIRO, R. M.; SOUZA, C. M.; SILVA, C. S. W.; SEDIYAMA, C. S.; SILVA, A. A.; FAGUNDES, J. L. Influência dos sistemas de preparo nas propriedades químicas e físicas do solo. Revista Brasileira de Ciência do Solo, v. 27, n. 6, p. 1097-1104, 2003. https://doi.org/10.1590/S0100-06832003000600014

GAMMA DESING SOFTWARE. Geoestatistics for the environmental sciences. Version 9.0 for Windows, Michigan, 2000. CD ROM.

GUEDES FILHO, O.; VIEIRA, S. R.; CHIBA, M. K.; NAGUMO, C. H.; DECHEN, S. C. F. Spatial and temporal variability of crop yield and some Rhodic Hapludox properties under no-tillage. Revista Brasileira de Ciência do Solo, v. 34, n. 1, p. 1-14, 2010. https://doi.org/10.1590/S0100-06832010000100001

LEITE, L. F. C.; GALVÃO, S. R. S.; HOLANDA NETO, M. R.; ARAÚJO. F. S.; IWATA, B. F. Atributos químicos e estoques de carbono em Latossolo sob plantio direto no cerrado do Piauí. Revista Brasileira de Engenharia Agrícola e Ambiental, v.14, n. 12, p 1273-1280, 2010. https://doi.org/10.1590/S141543662010001200004

MACHADO, L. O.; LANA, A. M. Q.; LANA, R. M. Q; GUIMARÃES, E. C.; FERREIRA, C. V. Variabilidade espacial de atributos químicos do solo em áreas sob sistema plantio convencional. Revista Brasileira de Ciência do Solo, v. 31, n. 3, p. 591-599, 2007. https://doi.org/10.1590/S010006832007000300019

MACIEL, C. A. C.; CAMARGO, O. A.; VIEIRA, S. R.; CHIBA, M. K. Distribuição espacial de cobre, zinco e níquel em um Latossolo após quinze anos da aplicação de lodo de esgoto. Bragantia, v. 71, n. 4, p. 528-537, 2012. https://doi.org/10.1590/S0006-87052013005000008

MARQUES JÚNIOR, J.; SOUZA, Z. M.; PEREIRA, G. T.; BARBIERI, D. M. Variabilidade espacial de matéria orgânica, P, K e CTC de um Latossolo cultivado com cana de açúcar por longo período. Revista de Biologia e Ciências da Terra, v. 8, n. 1, p. 143-152, 2008.

MCBRATNEY, A. B.; WEBSTER, R. How many observations are needed for regional estimation of soil properties? Soil Science, v. 135, n. 3, p. 177-183, 1983. https://doi.org/10.1097/00010694-198303000-00007

MERTEN, G. H. Relatório de experimento de pesquisa - Avaliação da erosão em sistemas de preparo e rotação de culturas em macroparcelas. Ponta Grossa, Brochura do Instituto Agronômico do Paraná, 1995.

NEGREIROS NETO, J. V.; SANTOS, A. C.; GUARNIERI, A.; SOUZA, D. J. A. T.; DARONCH, D. J.; DOTTO, M. A.; ARAÚJO, A. S. Variabilidade espacial de atributos físico-químicos de um Latossolo Vermelho-Amarelo distrófico em sistema plantio direto. Semina Ciência Agrárias, v. 35, n. 1, p. 193-204, 2014. https://doi.org/10.5433/1679-0359.2014v35n1p193 
PAVAN, M. A.; BLOCH, M. F.; ZEMPULSKI, H. D.; MIYAZAWA, M.; ZOCOLER, D. C. Manual de análise química de solo e controle de qualidade. Londrina, Instituto Agronômico do Paraná, 1992. 40 p. (Circular, 76).

RAIJ, B. VAN; SILVA, N. M.; CANTARELlA, H.; QUAGGIO, J. A.; FURLANI, A. M. C. Recomendações de adubação e calagem para o estado de São Paulo. $2^{a}$ ed. Campinas: Instituto Agronômico. 1997. 285 p.

SANTOS, H. G.; JACOMINE, P. K. T.; ANJOS, L. H. C.; OLIVEIRA, V. A.; LUBRERAS, J. F.; COELHO, M. R.; ALMEIDA, J. A.; CUNHA, T. J. F.; OLIVEIRA, J. B., eds. Sistema brasileiro de classificação de solos. 4.ed. Brasília, Embrapa, 2013. 376 p.

SCHLINDWEIN, J. A.; ANGHINONI, I. Variabilidade horizontal de atributos de fertilidade e amostragem do solo no sistema plantio direto. Revista Brasileira de Ciência do Solo, v. 24, n. 1, p. 85-91, 2000. https://doi.org/10.1590/S0100-06832000000100011

SILVA, F. C. da. Manual de análises químicas de solos, plantas e fertilizantes. Brasília: Embrapa Comunicação para Transferência de Tecnologia, 1999. 370 p.

SOIL SURVEY STAFF. Keys to soil taxonomy. 11 ed. Washington, DC, USDA/NRCS, 2010. 338 p.

SOUZA, Z. M. de; SOUZA, G. S. de. Número de amostras na análise geoestatística e krigagem de mapas de atributos do solo. Ciência Rural, v. 44, n. 2, p. 261-268, 2014. https://doi.org/10.1590/S010384782014000200011

SOUZA, G. S.; LIMA, J. S. S. de; XAVIER, A. C.; ROCHA, W. S. D. da. Krigagem ordinária e inverso do quadrado da distância aplicados na espacialização de atributos químicos de um argissolo. Scientia Agraria, v. 11, n. 1, p. 73-81, 2010. https://doi.org/10.5380/rsa.v11i1.15939

SOUZA, L. S.; COGO, N. P.; VIEIRA, S. R. Variabilidade de propriedades físicas e químicas do solo em um pomar cítrico. Revista Brasileira de Ciência do Solo, v. 21, n. 3, p. 367-372, 1997.

https://doi.org/10.1590/S0100-06831997000300003

VIAN, A. L.; SANTI, A. L.; CHERUBIN, M. R.; EITELWEIN, M. T.; DAMIAN, J. M. Distribuição espacial de micronutrientes em áreas de Latossolo irrigados e sequeiro manejadas com agricultura de precisão.

Enciclopédia Biosfera, v. 8, n. 14, p. 508-422, 2012.

VIEIRA, S. R.; HATFIELD, J.L.; NIELSEN, D. R.; BIIGGAR, J. W. Geostatistical theory and application to variability of some agronomical properties. Hilgardia, 51, n. 3, p. 1-75, 1983.

https://doi.org/10.3733/hilg.v51n03p075

VIEIRA, S. R.; DECHEN, S. C. F.; SIQUEIRA, G. M.; DUFRANC, G. Variabilidade espacial de atributos físicos e químicos relacionados com o estado de agregação de dois Latossolos cultivados no sistema de semeadura direta. Bragantia, v. 70, n. 1, p. 185-195, 2011. https://doi.org/10.1590/S0006-87052011000100025

ZANÃO JÚNIOR, L. A.; LANA, R. M. Q.; GUIMARÃES, E. C.; PEREIRA, J. M. A. Variabilidade espacial dos teores de macronutrientes em Latossolos sob sistema plantio direto. Revista Brasileira de Ciência do Solo, v. 34, n. 2, p. 389-400, 2010. https://doi.org/10.1590/S0100-06832010000200012

ZONTA, J. H.; BRANDÃO, Z. N.; MEDEIROS, J. C.; SANA, R. S.; SOFIATTI, V.Variabilidade espacial da fertilidade do solo em área cultivada com algodoeiro no cerrado do Brasil. Revista Brasileira de Engenharia Agrícola e Ambiental, v. 18, n. 6, p. 595-602, 2014. https://doi.org/10.1590/S1415-43662014000600005

WARRICK, A. W.; NIELSEN, D. R. Spatial variability of soil physical properties in the field. In: HILLEL, D. Applications of soil physics. New York: Academic Part 2, 1980. p. 319- 44. https://doi.org/10.1016/B978-012-348580-9.50018-3

WEBSTER, R.; OLIVER, M. A. Geostatistics for environmental scientists. $2^{\mathrm{a}}$ ed. Chichester: John Wiley and Sons, 2007. 318 p. https://doi.org/10.1002/9780470517277 